University of Nebraska - Lincoln

DigitalCommons@University of Nebraska - Lincoln

\title{
A Continuous 250,000 Yr Record of Oxygen and Carbon Isotopes in Ostracode and Bulk-Sediment Carbonate from Bear Lake, Utah- Idaho
}

Walter E. Dean

U.S. Geological Survey, Denver, CO, dean@usgs.gov

Jordon Bright

Department of Geology and Quaternary Sciences Program, Northern Arizona University, Flagstaff, AZ 86011-4099, USA

Darrell S. Kaufman

Department of Geology and Quaternary Sciences Program, Northern Arizona University, Flagstaff, AZ 86011-4099, USA

Richard M. Forester

US Geological Survey, Federal Center, Denver, Co 80225, USA

Follow this and additional works at: https://digitalcommons.unl.edu/usgsstaffpub

Part of the Earth Sciences Commons

Dean, Walter E.; Bright, Jordon; Kaufman, Darrell S.; and Forester, Richard M., "A Continuous 250,000 Yr Record of Oxygen and Carbon Isotopes in Ostracode and Bulk-Sediment Carbonate from Bear Lake, UtahIdaho" (2006). USGS Staff -- Published Research. 318.

https://digitalcommons.unl.edu/usgsstaffpub/318

This Article is brought to you for free and open access by the US Geological Survey at DigitalCommons@University of Nebraska - Lincoln. It has been accepted for inclusion in USGS Staff -- Published Research by an authorized administrator of DigitalCommons@University of Nebraska - Lincoln. 


\title{
A continuous $250,000 \mathrm{yr}$ record of oxygen and carbon isotopes in ostracode and bulk-sediment carbonate from Bear Lake, Utah-Idaho
}

\author{
Jordon Bright ${ }^{\mathrm{a}}$, Darrell S. Kaufman ${ }^{\mathrm{a}, \mathrm{b}, *}$, Richard M. Forester ${ }^{\mathrm{c}}$, Walter E. Dean ${ }^{\mathrm{c}}$ \\ ${ }^{a}$ Department of Geology and Quaternary Sciences Program, Northern Arizona University, Flagstaff, AZ 86011-4099, USA \\ ${ }^{\mathrm{b}}$ Department of Environmental Sciences, Northern Arizona University, Flagstaff, AZ 86011, USA \\ ${ }^{\mathrm{c}}$ US Geological Survey, Federal Center, Denver, CO 80225, USA
}

Received 22 February 2005; accepted 19 December 2005

\begin{abstract}
Oxygen and carbon isotopes from a continuous, 120-m-long, carbonate-rich core from Bear Lake, Utah-Idaho, document dramatic fluctuations in the hydrologic budget of the lake over the last 250,000 yr. Isotopic analyses of bulk sediment samples capture millennialscale variability. Ostracode calcite was analyzed from 78 levels, mainly from the upper half of the core where valves are better preserved, to compare the isotopic value of purely endogenic carbonate with the bulk sediment, which comprises both endogenic and detrital components. The long core exhibits three relatively brief intervals with abundant endogenic aragonite $(50 \pm 10 \%)$ and enriched $\delta^{18} \mathrm{O}$ and $\delta^{13} \mathrm{C}$. These intervals are interpreted as warm/dry periods when the lake retracted into a topographically closed basin. We correlate these intervals with the interglacial periods of marine oxygen-isotope stages $1,5 \mathrm{e}$, and $7 \mathrm{a}$, consistent with the presently available geochronological control. During most of the time represented by the core, the lake was fresher than the modern lake, as evidenced by depleted $\delta^{18} \mathrm{O}$ and $\delta^{13} \mathrm{C}$ in bulk-sediment carbonate.
\end{abstract}

(C) 2006 Elsevier Ltd. All rights reserved.

\section{Introduction}

Bear Lake, Utah-Idaho (Fig. 1), is one of the longestlived, carbonate-generating lakes in North America. In September 2000, a new coring platform, "Global Lake Drilling to 800 Meters (GLAD800)" was tested in the lake as part of a collaborative effort aimed at understanding the paleoclimate history of the region (http://dosecc.org/html/ utah_lakes.html; http://climchange.cr.usgs.gov/info/lacs/ index.html). The trials produced two continuous cores, 100 and $120 \mathrm{~m}$ long, taken adjacent to one another in $\sim 53 \mathrm{~m}$ of water. They encompass one of the longest Quaternary sedimentary records from a continuously inundated lake basin that we know of on the continent.

Our objective here is to use the oxygen and carbon isotopes from bulk-sediment carbonate and ostracode calcite to reconstruct millennial-scale hydrologic changes at Bear Lake. We focus on the longer core, GLAD800-00-1E

\footnotetext{
*Corresponding author. Department of Geology, Northern Arizona University, Flagstaff, AZ 86011-4099, USA. Tel.: + 19285237192.

E-mail address: Darrell.Kaufman@nau.edu (D.S. Kaufman).
}

(hereafter, "00-1E"), which spans roughly a quarter million years (Dean et al., 2002; Colman et al., in press). We describe the modern Bear Lake system using hydrologic and stable-isotope data from the local streams, the Bear River, and the lake itself. The modern data provide context for interpreting down-core changes measured in core $00-1 \mathrm{E}$.

\section{Geographic and hydrologic setting}

Bear Lake straddles the border between northeastern Utah and southeastern Idaho (Fig. 1). The lake has a surface area of $282 \mathrm{~km}^{2}$, a maximum depth of $63 \mathrm{~m}$, and a volume of $8.0 \times 10^{9} \mathrm{~m}^{3}$. The lake is presently confined to the southern half of Bear Lake valley, an east-tilted half grabben, bounded by active faults (McCalpin, 1993). On the west, the Bear River Range, with a maximum elevation of approximately $3030 \mathrm{~m}$, is underlain by a thick sequence of Paleozoic marine carbonates, with minor shales and quartzites (Dover, 1995; Oriel and Platt, 1980). To the east, the Bear Lake Plateau, with a maximum elevation of approximately $2270 \mathrm{~m}$, is composed mainly of early 


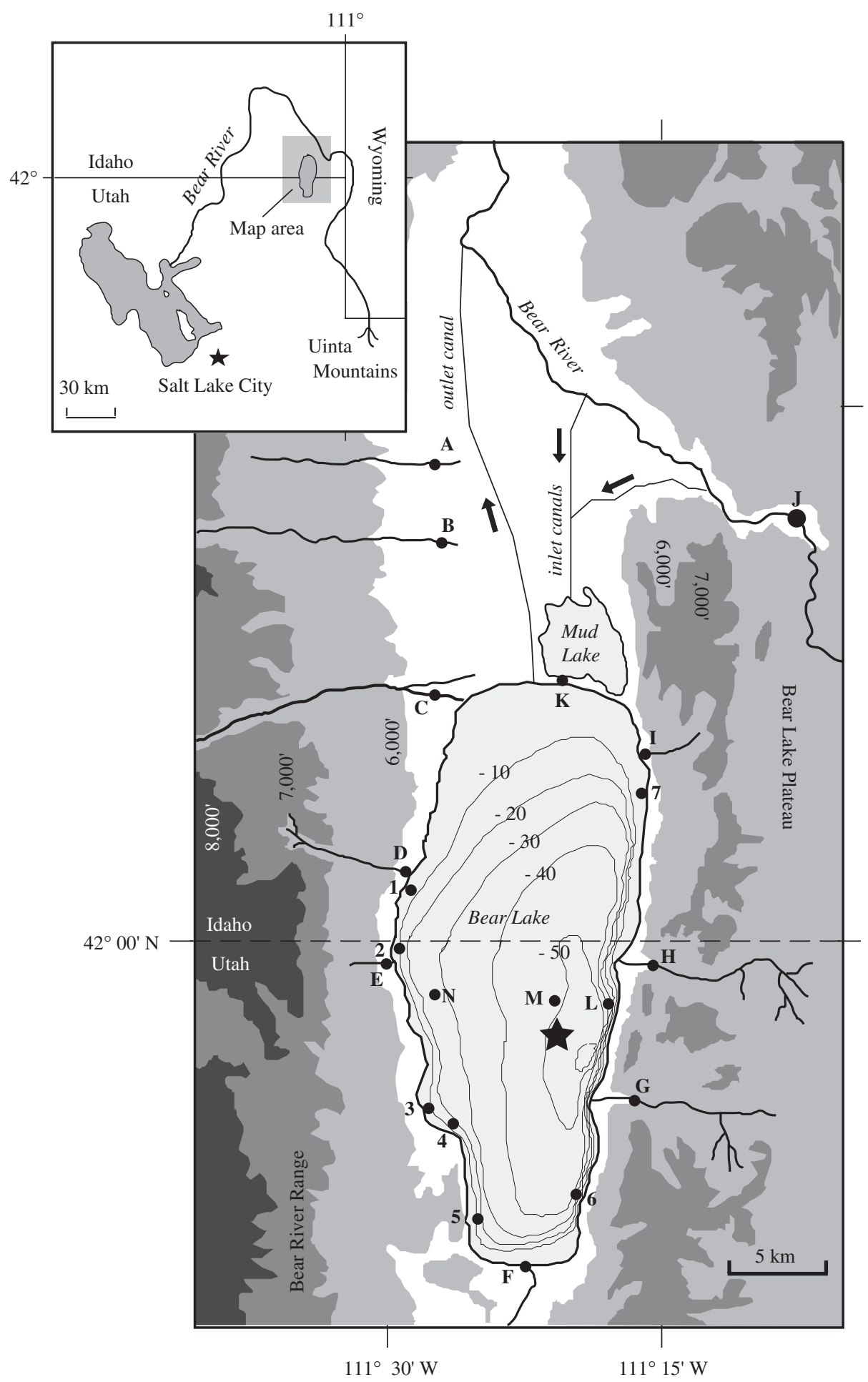

Fig. 1. Bear Lake valley showing water-sample sites. A-J are stream sample sites; $\mathrm{K}$ is inlet from Mud Lake to Bear Lake; and L-N are lake sample sites. Sites 1-7 are recently exposed spring and seep locations; star is location of core 00-1E. Lake bathymetry is in meters.

Mesozoic and Tertiary limestones, sandstones, and shales (Dover, 1995; Oriel and Platt, 1980).

Precipitation varies markedly from west to east across the catchment area. The Bear River Range captures most of the moisture from the prevailing westerly storms. Annual precipitation in the Bear River Range (1979-2003, Tony Grove Lake, elevation 2415 m) averages
$125 \mathrm{~cm} \mathrm{yr}^{-1}$ with the majority falling in the winter (http:// wcc.nrcs.usda.gov/snow/). Precipitation has not been measured on the Bear Lake Plateau, but three stations at lower elevation surrounding Bear Lake average approximately $30.5 \mathrm{~cm} \mathrm{yr}^{-1}$, with a slight majority falling in the winter (http://wrcc.sage.dri.edu/summary/climsmid and http://wrcc.sage.dri.edu/summary/climsmut.html). 
Four large spring-fed streams originating in the Bear River Range and three small spring-fed streams from the Bear Lake Plateau drain into Bear Lake (sites C-I; Fig. 1). Dye tests indicate that groundwater flowpaths in the Bear River Range cross geographic divides (Spangler, 2001), suggesting that a portion of the streamflow may be extrabasinal. A conservative estimate suggests that, prior to the diversion of Bear River water into the lake ca. 1912, the Bear River Range accounted for at least $80 \%$ of the surface water delivered to Bear Lake (Fig. 2). Available instrumental records, combined with an evaporation rate of $0.56 \mathrm{~m} \mathrm{yr}^{-1}$ estimated by Amayreh (1995), suggest that the hydrologic budget of the pre-diversion Bear Lake was

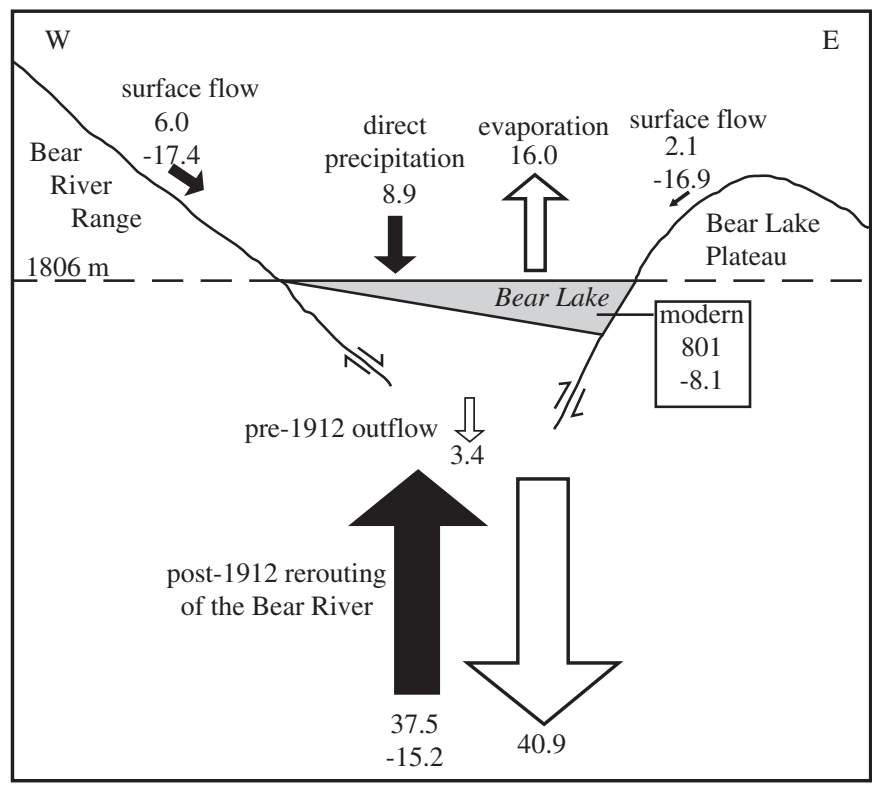

Fig. 2. Schematic illustration of the hydrologic budget at Bear Lake, preand post-1912 Bear River diversion. Solid arrows are input terms; open arrows are output terms; input and output values are $\times 10^{7} \mathrm{~m}^{3} \mathrm{yr}^{-1}$. Local stream input values are approximate, and based on data from Bright (2003). Bear River diversion values are based on 50-yr averaged data from the Utah Department of Natural Resources "Bear River Flow Chart". Evaporation and direct precipitation values are from Bright (2003). The $\delta^{18} \mathrm{O}$ values of all water samples (negative values) are based on modern collections and are in \%o Vienna Standard Mean Ocean Water. Data are listed in Tables 1 and 2. balanced, or nearly so (Table 1), consistent with reports of a small outlet channel that intermittently drained northward from the lake (McConnell et al., 1957; Williams et al., 1962). Furthermore, instrumental records following the diversion indicate that slightly more water was released from Bear Lake than was diverted into it. A single analysis of lake water from 1912 yielded a total dissolved solid (TDS) load of $\sim 1060 \mathrm{mg} \mathrm{L}^{-1}$ (Birdsey, 1989).

Solute input to the lake is dominated by the dissolution of Bear River Range marine carbonates, so is composed mostly of calcium $(\mathrm{Ca})$, magnesium $(\mathrm{Mg})$ and bicarbonate. When Bear Lake is topographically closed, and its water loss is primarily through evaporation, it reaches carbonate mineral saturation resulting in an elevated lake $\mathrm{Mg} / \mathrm{Ca}$ ratio as most of the calcium is lost to carbonate production (e.g. Eugster and Jones, 1979). Aragonite has been the dominant carbonate phase produced in Bear Lake throughout the Holocene and should be the dominant carbonate phase whenever the lake is topographically closed and evaporation dominates the hydrologic system.

The contribution of sub-lacustrine and lake-marginal springs to the hydrologic and isotopic budget of the lake is unknown. Recent drought conditions have lowered lake level by over $6 \mathrm{~m}$ exposing several lake-marginal seeps and springs (sites 1-7; Fig. 1). An unknown number of other sub-lacustrine spring sites are probably still submerged.

The natural channel of the Bear River presently bypasses Bear Lake $13 \mathrm{~km}$ to the north (Fig. 1). The Bear River has its headwaters in the Uinta Mountains approximately $150 \mathrm{~km}$ south of Bear Lake. A series of canals constructed between AD 1909 and 1918 connected Bear River to the lake and converted the lake into a reservoir (Birdsey, 1989). Canal construction was essentially complete by 1912, and we use this date as the nominal date of diversion. Each spring, Bear River flow is diverted via Mud Lake into Bear Lake where it is stored and released downstream later in the summer. The Bear River now accounts for roughly $80-85 \%$ of the surface water entering Bear Lake (Fig. 2). This diversion of Bear River water through Bear Lake over the last $90 \mathrm{yr}$ has reduced the TDS load of the lake to about $500 \mathrm{mg} \mathrm{L}^{-1}$ (Table 1). The cyclical flushing of Bear River water has reduced the $\mathrm{Mg} / \mathrm{Ca}$ and the lake now precipitates high-Mg calcite.

Table 1

Hydrologic data for bear lake with and without the input of the Bear River

\begin{tabular}{llcr}
\hline & Units of measure & Pre-1912 & Modern w/Bear River \\
\hline Local stream/spring inflow/direct precipitation $^{\mathrm{a}}$ & $\times 10^{7} \mathrm{~m}^{3}$ & 17.0 & 17.0 \\
Evaporation $^{\mathrm{b}}$ & $\times 10^{7} \mathrm{~m}^{3}$ & -16.0 & -16.0 \\
Total dissolved solids (TDS) $^{\mathrm{c}}$ & $\mathrm{mg} \mathrm{\textrm {L } ^ { - 1 }}$ & $\sim 1060$ & $\sim 500$ \\
Bear river inflow $^{7}$ & $\times 10^{7} \mathrm{~m}^{3}$ & 0 & $37.5^{\mathrm{d}}$ \\
Outflow $^{\mathrm{d}}$ & $\times 10^{7} \mathrm{~m}^{3}$ & $3.4^{\mathrm{d}}$ & $40.9^{\mathrm{d}}$ \\
\hline
\end{tabular}

${ }^{a}$ Modern inflow values based on drainage areas and modern precipitation as discussed by Bright (2003).

${ }^{\mathrm{b}}$ Modern evaporation based Amayreh (1995).

${ }^{\mathrm{c}}$ Pre-1912 TDS based on Birdsey (1989); modern TDS based on unpublished US Geological Survey data.

${ }^{\mathrm{d}}$ Values from Utah Department of Natural Resources, Division. of Water Resources, "Bear River Flowchart". 
The Bear River has delivered water to Bear Lake at other times prior to the 1912 diversion. The lake level is presently only a few meters below its topographic threshold, and there are no obvious geomorphic features capable of impounding a higher lake. However, geomorphic and stratigraphic evidence, coupled with amino acid geochronology, indicate that the level of Bear Lake exceeded the present level several times during the Quaternary (Laabs and Kaufman, 2003). Because of the basin morphology, Bear River and Bear Lake would have mixed whenever the lake expanded northward and intersected the channel of the Bear River.

\section{Sampling and analytical methods}

\subsection{Water sample collection}

Water samples for stable isotope analyses were collected from nine streams surrounding Bear Lake (Fig. 1, sites A-J) during spring runoff (May 2003; April 2004), and during late-summer minimum flow (September 2003; August 2004). Water was collected from the surface of Bear Lake in 2003 and 2004 (Fig. 1, sites L, M, and N), and from seven lake-marginal springs (Fig. 1, sites 1-7) in 2004. The May 2003 collections were filtered at $1.2 \mu \mathrm{m}$; other samples were not filtered. Water for $\delta^{13} \mathrm{C}$ analyses was filtered at $0.2 \mu \mathrm{m}$ into amber bottles and crimp sealed. All samples were refrigerated until analyzed.

\subsection{Carbonate bedrock and detrital carbonate in local streams}

We sampled the majority of the major carbonate rock units from the surrounding highlands $(n=9)$, and sediment from the bed of inflow streams $(n=7)$. The finegrained fraction $(<63 \mu \mathrm{m})$ of the stream sediment was analyzed for oxygen and carbon isotopes. In addition, carbonate rock and tufa grains (150-250 $\mu \mathrm{m}$ size fraction) from one stream on both sides of Bear Lake were isolated and analyzed separately.

\subsection{Core 00-1E}

Core 00-1E was initially sampled at $1 \mathrm{~m}$ spacing ( $\sim 2000 \mathrm{yr}$ resolution) with each sample being $\sim 3 \mathrm{~cm}$ thick. The samples were washed over $150 \mu \mathrm{m}$ sieves to remove ostracode valves and sand-sized clastics. Ostracode valves are well preserved in the upper $65 \mathrm{~m}$ of core $00-1 \mathrm{E}$; below $65 \mathrm{~m}$ the valves are fragmented, and only the robust shells of Cytherissa lacustris are preserved whole (Bright and Kaufman, 2005). A total of 120 sieved $(<150 \mu \mathrm{m})$ bulksediment samples and 78 samples of the ostracode genus Candona (53 samples, 2-3 whole adult valves per analysis above $65 \mathrm{~m}$, and 25 samples, 4-6 adult fragments per analysis below $65 \mathrm{~m}$ ) were analyzed for oxygen and carbon isotopes. The core was then resampled $(n=255)$ to increase the bulk-sediment resolution to roughly
$30-40 \mathrm{~cm}$ spacing ( $700 \mathrm{yr})$, with each sample being $1 \mathrm{~cm}$ thick. Because of their small sizes, these samples were not sieved for ostracodes and were analyzed, in their entirety, as homogenized powders. A comparison of sieved versus non-sieved bulk sediment (Bright, 2003) showed no appreciable difference in the stable isotope values of samples with or without ostracode calcite.

\subsection{Stable isotope analyses}

\subsubsection{Water analyses}

Water for oxygen-isotope analysis was equilibrated with $\mathrm{CO}_{2}$ gas at approximately $15^{\circ} \mathrm{C}$ in an automated equilibration device coupled to a Finnigan Delta $\mathrm{S}$ mass spectrometer at the University of Arizona. Standardization is based on internal reference materials Vienna Standard Mean Ocean Water (VSMOW) and Standard Light Antarctic Precipitation (SLAP). Precision is $0.08 \%$ or better on the basis of repeated internal standards. For carbon-isotope analysis, two milliliters of water were reacted with $105 \% \mathrm{H}_{3} \mathrm{PO}_{4}$ at $20{ }^{\circ} \mathrm{C}$ in a vacuum line glass vessel. Internal laboratory standards composed of $\mathrm{Li}_{2} \mathrm{CO}_{3}$ and $\mathrm{Na}_{2} \mathrm{CO}_{3}$ were analyzed every 10 samples. Samples were injected onto a Finnigan MAT 252 mass spectrometer at the University of Minnesota. Raw data were normalized to NIST standards NBS-18 and NBS-19. Precision is $0.1 \%$ based on various repeated internal standards. Water isotopic ratios are reported using standard $\delta$-notation, where: $\delta \%=\left[\left(R_{\text {sample }} / R_{\text {std }}\right)-1\right] \times 10^{3}$; and $R=$ ratio of ${ }^{18} \mathrm{O}:{ }^{16} \mathrm{O}$ or ${ }^{13} \mathrm{C}:{ }^{12} \mathrm{C} . R_{\text {std }}$ refers to the standards Vienna Standard Mean Ocean Water (VSMOW) for oxygen and Vienna Peedee belemnite (VPDB) for carbon.

\subsubsection{Carbonate analyses}

All carbonate samples for isotopic analysis (including ostracodes) were baked under vacuum for $1 \mathrm{~h}$ at $180^{\circ} \mathrm{C}$ to remove volatiles that may interfere with measurement of the samples. Bulk sediment samples and ostracode calcite samples weighed approximately 1.0 and $0.4 \mathrm{mg}$, respectively. $\delta^{18} \mathrm{O}$ and $\delta^{13} \mathrm{C}$ of carbonates were measured using an automated carbonate preparation device (KIEL-III) coupled to a Finnigan MAT 252 gas-ratio mass spectrometer. Powdered samples were reacted with dehydrated phosphoric acid under vacuum at $70^{\circ} \mathrm{C}$. The isotope ratio measurement is calibrated based on repeated measurements of NBS-18 and NBS-19 and precision is $\pm 0.1 \%$ for $\delta^{18} \mathrm{O}$ and $\pm 0.06 \%$ for $\delta^{13} \mathrm{C}(1 \sigma)$. Carbonate isotopic ratios are reported using standard $\delta$-notation, where: $\delta \%=\left[\left(R_{\text {sample }} / R_{\text {std }}\right)-1\right] \times 10^{3}$; and $R=$ ratio of ${ }^{18} \mathrm{O}:{ }^{16} \mathrm{O}$ or ${ }^{13} \mathrm{C}:{ }^{12} \mathrm{C}$. $R_{\text {std }}$ refers to the VPDB standard.

\section{Results and discussion}

All of the oxygen- and carbon-isotope data on core 00-1E bulk-sediment carbonate and ostracode calcite are listed in Appendices A and B and plotted in Fig. 3. 


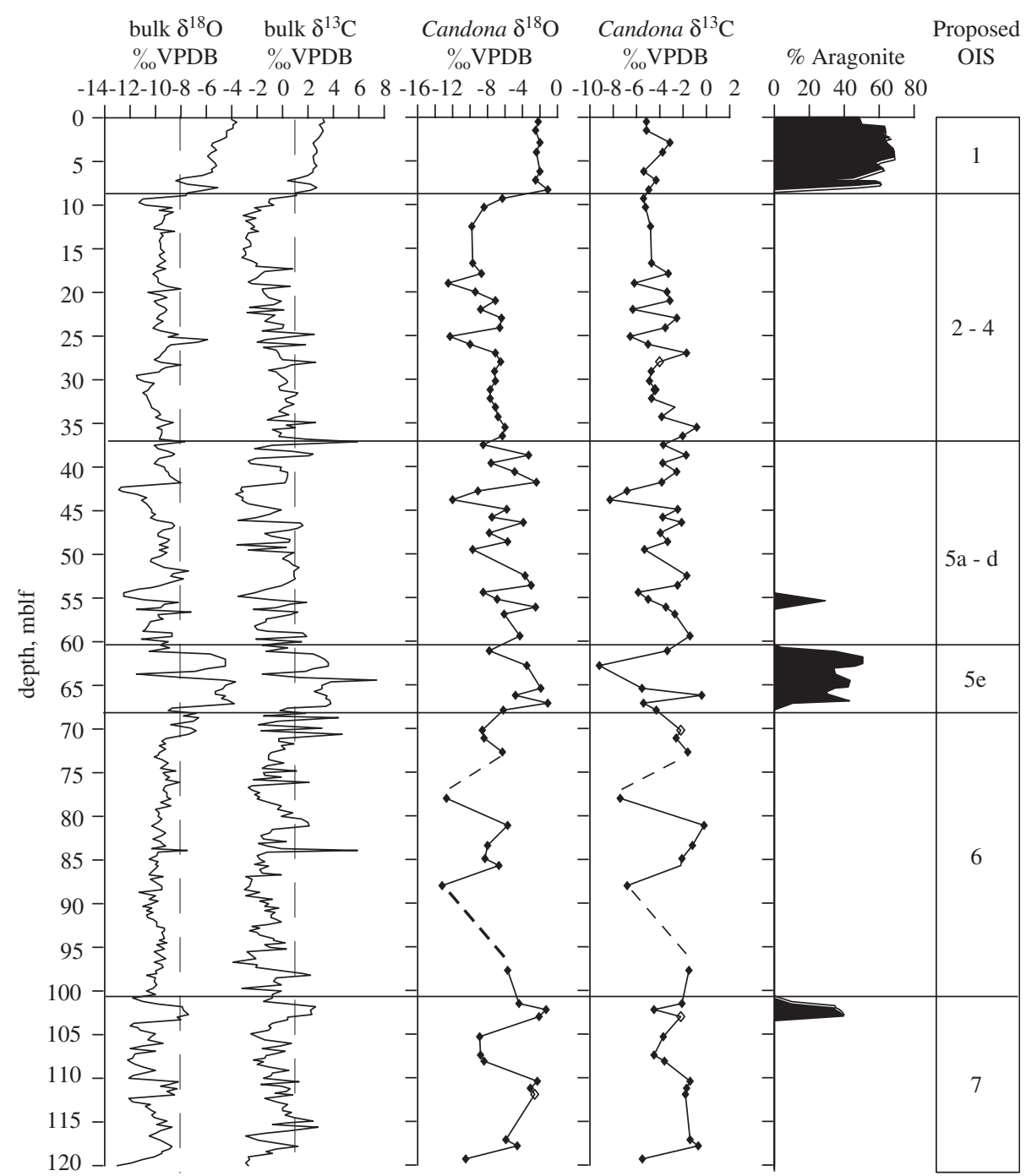

Fig. 3. $\delta^{18} \mathrm{O}, \delta^{13} \mathrm{C}$, and percent aragonite vs. depth for core 00-1E. The curves for bulk-sediment carbonate consist of 375 samples; values from Candona sp. (73 samples) are shown as solid diamonds. Dashed intervals represent long sections with no Candona sp. data. Correlative marine oxygen-isotope stages (OIS) are shown on right. Vertical dashed lines indicate the inferred detrital carbonate values. Stable isotope data are listed in Appendix A and B. $\%$ Aragonite is determined by X-ray diffraction (intensity of the main aragonite peak divided by the sum of the main peak intensities for all minerals).

\subsection{Present-day water $\delta^{18} \mathrm{O}$ and $\delta^{13} \mathrm{C}$ in the Bear Lake watershed}

The average $\delta^{18} \mathrm{O}$ of surface water inflow $\left(\delta^{18} \mathrm{O}_{\text {inflow }}\right)$ is similar for west-side $(-17.4 \pm 0.7 \%, n=40)$ and east-side $(-17.0 \pm 0.8 \%, n=10)$ streams and springs (sites $\mathrm{A}-\mathrm{I}$ and $1-7)$ (Table 2). The average $\delta^{18} \mathrm{O}$ of the Bear River is similar to the local water sources, averaging $-16.3 \pm 0.4 \%$ o $(n=4$, site J). Bear River water routed into Bear Lake is detained in Mud Lake (site K), where the $\delta^{18} \mathrm{O}$ is $-15.2 \%$. Further evaporation in Bear Lake enriches $\delta^{18} \mathrm{O}_{\text {lake }}$ to $-8.1 \pm 0.1 \%$ $\left(n=6\right.$; sites $\mathrm{L}-\mathrm{N}$; Table 2). The average $\delta^{13} \mathrm{C}$ of stream inflow $\left(\delta^{13} C_{\text {inflow }}\right)$ is also similar for west-side $(-9.7 \pm 0.2 \%$, $n=5$; sites $\mathrm{A}-\mathrm{E})$ and east-side $(-9.2 \pm 1.4 \%, n=2$; sites $\mathrm{H}-\mathrm{I})$ streams (Table 2). The $\delta^{13} \mathrm{C}$ of the Bear River $(-8.9 \%$; site $\mathbf{J}$ ) is again similar to the local water sources. Isotopic enrichment (e.g. biologic processes, degassing, etc.) within Bear Lake increases $\delta^{13} \mathrm{C}_{\text {lake }}$ to $-2.2 \%$ (site L).

\subsection{Influence of detrital carbonate}

The bulk sediment of Bear Lake contains a variable mixture of endogenic and detrital carbonate. While the flux of detrital carbonate changes over time, $\delta^{18} \mathrm{O}_{\text {detrital }}$ and $\delta^{13} \mathrm{C}_{\text {detrital }}$ probably remain relatively constant, reflecting the integrated composition of carbonate detritus within the drainages. Detrital carbonate may obscure or overwhelm the endogenic carbonate depending on the relative proportion of endogenic to detrital carbonate in the bulk sediment. Therefore, changes in the isotopic ratios of bulk sediment $\left(\delta^{18} \mathrm{O}_{\text {bulk }}\right.$ and $\left.\delta^{13} \mathrm{C}_{\text {bulk }}\right)$, although possibly related to climatic changes, may also result from geomorphic changes that physically shift the endogenic/detrital-carbonate ratio in the bulk sediment, independently of climate.

Carbonate rocks surrounding Bear Lake exhibit a wide range of $\delta^{18} \mathrm{O}(-5$ to $-13 \%)$ and $\delta^{13} \mathrm{C}$ values ( -2 to $\left.3 \%\right)$ (Table 3). These values are lower than typical marine 


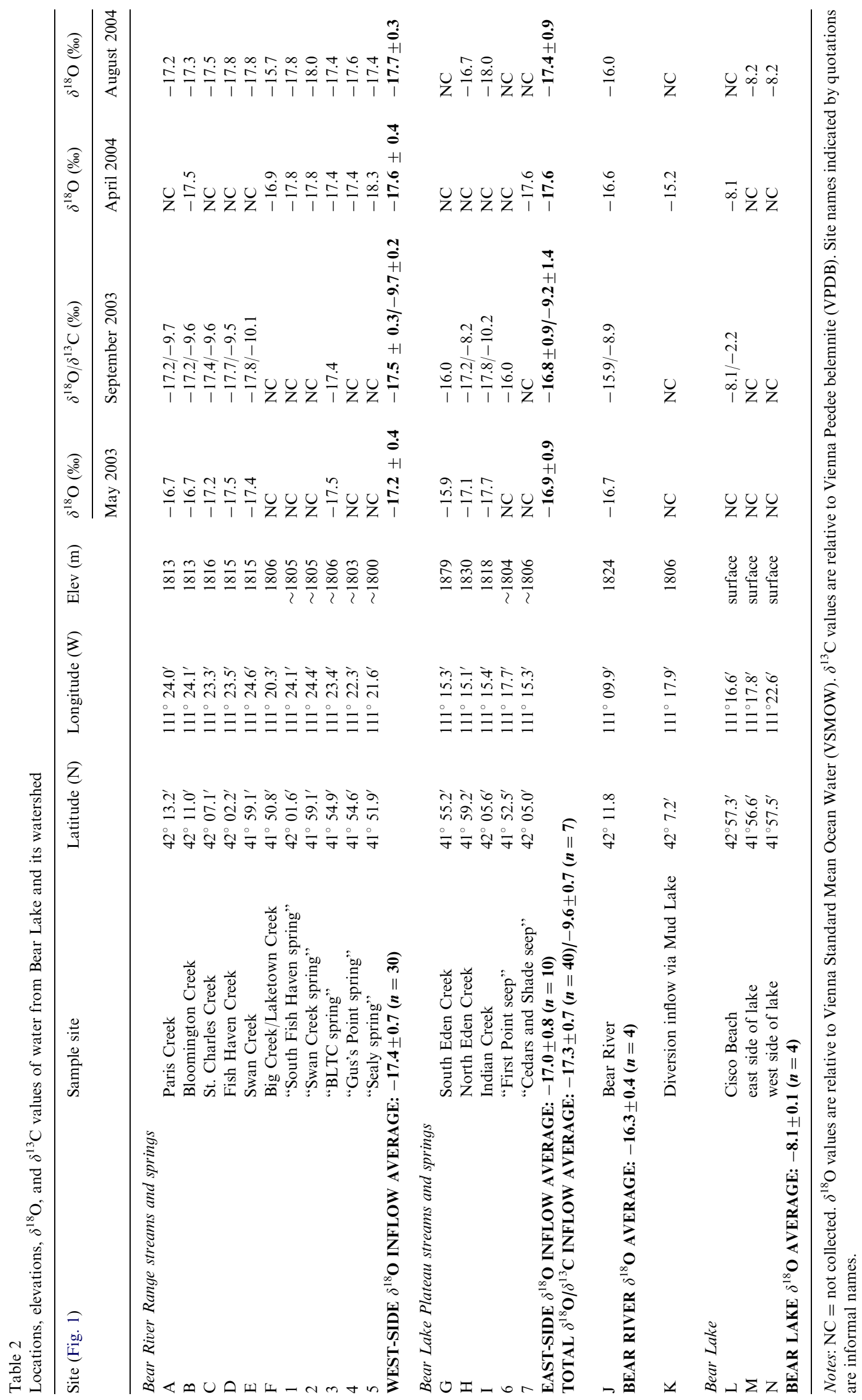


carbonate rock suggesting that the local bedrock has been isotopically altered, presumably due to burial and isotopic modification at higher than earth-surface temperatures. Fine-grained $(<63 \mu \mathrm{m})$ carbonate detritus in stream sediment from the Bear River Range and Bear Lake Plateau (sites A-C, E, and sites G-I, respectively) vary less, having $\delta^{18} \mathrm{O}_{\text {detrital }}$ and $\delta^{13} \mathrm{C}_{\text {detrtial }}$ values of $-13.6 \pm 1.3$ and $-5.8 \pm 1.1 \%$ o $(n=7)$, respectively (Table 4$)$. An aggregate of hand-picked carbonate rock fragments from one Bear River Range stream (site E) produced $\delta^{18} \mathrm{O}$ and $\delta^{13} \mathrm{C}$ values of -9.3 and $-1.1 \%$, respectively, whereas hand-picked tufa from the same stream sediment produced $\delta^{18} \mathrm{O}$ and $\delta^{13} \mathrm{C}$ values of -16.2 and $-7.3 \%$, respectively. A similar analysis of rock and tufa fragments in one Bear Lake Plateau stream (site $\mathrm{H}$ ) yielded $\delta^{18} \mathrm{O}$ and $\delta^{13} \mathrm{C}$ values of -6.5 and $3.0 \%$, respectively, for rocks, and -15.5 and $-6.4 \%$, respectively, for tufa.

Although the tufa skews the isotopic value of the bulk carbonate carried by inflowing streams, it does not seem to

Table 3

$\delta^{18} \mathrm{O}$ and $\delta^{13} \mathrm{C}$ values of carbonate rocks of the Bear Lake watershed

\begin{tabular}{llc}
\hline Age-Unit (lithology) & $\delta^{18} \mathrm{O}(\%)$ & $\delta^{13} \mathrm{C}(\%)$ \\
\hline Jurassic-Twin Creek Limestone & -7.4 & 1.0 \\
Mississippian-Lodgepole Limestone & -5.5 & 2.8 \\
Devonian-Hyrum Dolomite & -7.1 & -1.8 \\
Silurian-Laketown Dolomite & -5.1 & 0.9 \\
Silurian/Ordovician-Fish Haven Dolomite & -5.6 & 0.2 \\
Ordovician -Garden City Fm. (limestone) & -9.6 & -1.3 \\
Cambrian-St. Charles Fm. (limestone) & -9.9 & 0.9 \\
Cambrian-Bloomington Fm. (limestone) & -10.3 & -0.8 \\
Cambrian-Blacksmith Dolomite & -13.3 & 1.4 \\
Average (n=9) & $\mathbf{- 8 . 2 \pm \mathbf { 2 . 7 }}$ & $\mathbf{0 . 4} \pm \mathbf{1 . 4}$ \\
\hline
\end{tabular}

Note: All rocks were collected from the Bear River Range, except for the Twin Creek Limestone, which is from the Bear Lake Plateau. Isotopic values relative to Vienna Peedee belemnite (VPDB). impact the $\delta^{18} \mathrm{O}_{\text {bulk }}$ and $\delta^{13} \mathrm{C}_{\text {bulk }}$ of the aragonitic sediments in ${ }^{18} \mathrm{O}$ core $00-1 \mathrm{E}$, which are more enriched than the tufa (Fig. 4). During periods of aragonite production the endogenic carbonate component in the bulk sediment probably overwhelms any detrital (both tufa and bedrock) influences. Detrital carbonate may have a larger impact on $\delta^{18} \mathrm{O}_{\text {bulk }}$ and $\delta^{13} \mathrm{C}_{\text {bulk }}$ over the nonaragonite intervals in core $00-1 \mathrm{E}$. In some sections of core $00-1 \mathrm{E}$, carbonate (determined by coulometry) makes up $\leqslant 25 \%$ of the total bulk sediment (Dean et al., unpublished data), and $\delta^{18} \mathrm{O}_{\text {bulk }}$ and $\delta^{13} \mathrm{C}_{\text {bulk }}$ often approach the aggregate bedrock values (Figs. 3 and 4). This suggests that detrital bedrock is a significant component in these sediments. We assume that the detrital carbonate reaching the core site is a mix of west- and east-side rock sources, and we take the average $\delta^{18} \mathrm{O}$ and $\delta^{13} \mathrm{C}$ of hand-picked carbonate grains (not tufa) from the bed of Swan Creek and North Eden Creek $(-8 \pm 1.0$ and $1 \pm 1.0 \%$, respectively; Table 4) as an estimate for the carbonate detritus that reaches the site of core $00-1 \mathrm{E}$. Most of the $\delta^{18} \mathrm{O}_{\text {bulk }}$ and $\delta^{13} \mathrm{C}_{\text {bulk }}$ values fall well above or below the detrital estimates, however, suggesting that detrital carbonate generally does not dominate the bulk sediment (Figs. 3 and 4).

\subsection{Isotopes in ostracode calcite}

Like other endogenic calcite, the isotopic value of ostracode valves depends on the isotopic value of the water mass at the time of valve calcification (e.g. von Grafenstein, 2002). Because ostracodes do not incorporate detrital carbonate in their valves, they are often better indicators of lake-water isotopic ratios than bulk sediment. On the other hand, because some ostracodes burrow into the sediment to calcify their valves, the isotope values may reflect sediment pore-water chemistry rather than the

Table 4

$\delta^{18} \mathrm{O}$ and $\delta^{13} \mathrm{C}$ values of sediment and tufa from streams discharging into Bear Lake

\begin{tabular}{|c|c|c|c|c|}
\hline Site (Fig. 1) & Site name & Material & $\delta^{18} \mathrm{O}(\%)$ & $\delta^{13} \mathrm{C}(\%)$ \\
\hline A & Paris Creek & $<63 \mu \mathrm{m}$ bulk sediment & -14.3 & -6.1 \\
\hline B & Bloomington Creek & $<63 \mu \mathrm{m}$ bulk sediment & -15.8 & -7.2 \\
\hline $\mathrm{C}$ & St. Charles Creek & $<63 \mu \mathrm{m}$ bulk sediment & -13.0 & -5.7 \\
\hline $\mathrm{E}$ & Swan Creek & $<63 \mu \mathrm{m}$ bulk sediment & -13.4 & -5.2 \\
\hline G & South Eden Creek & $<63 \mu \mathrm{m}$ bulk sediment & -13.4 & -7.2 \\
\hline $\mathrm{H}$ & North Eden Creek & $<63 \mu \mathrm{m}$ bulk sediment & -13.5 & -4.8 \\
\hline I & Indian Creek & $<63 \mu \mathrm{m}$ bulk sediment & -11.6 & -4.5 \\
\hline AVERAGE $(n=7)$ & & & $-13.6 \pm 1.3$ & $-5.8 \pm 1.1$ \\
\hline A & Paris Creek & tufa & -15.4 & -5.8 \\
\hline $\mathrm{E}$ & Swan Creek & tufa & -16.2 & -7.3 \\
\hline $\mathrm{H}$ & North Eden Creek & tufa & -15.5 & -6.4 \\
\hline AVERAGE $(n=3)$ & & & $-15.7 \pm 0.4$ & $-6.5 \pm 0.8$ \\
\hline $\mathrm{E}$ & Swan Creek Creek ${ }^{\mathrm{a}}$ & carbonate rock & -9.3 & -1.1 \\
\hline $\mathrm{H}$ & North Eden Creek ${ }^{b}$ & carbonate rock & -6.5 & 3.0 \\
\hline AVERAGE $(n=2)$ & & & $-7.9 \pm 2.0$ & $1.0 \pm 2.9$ \\
\hline
\end{tabular}

Note: Isotopic values relative to Vienna Peedee belemnite (VPDB). Averaged values are depicted in Fig. 4.

${ }^{a}$ Swan Creek drainage contains Ordovician Garden City Fm. and older units (Table 3).

${ }^{\mathrm{b}}$ North Eden Creek drainage contains Jurassic Twin Creek Limestone. 

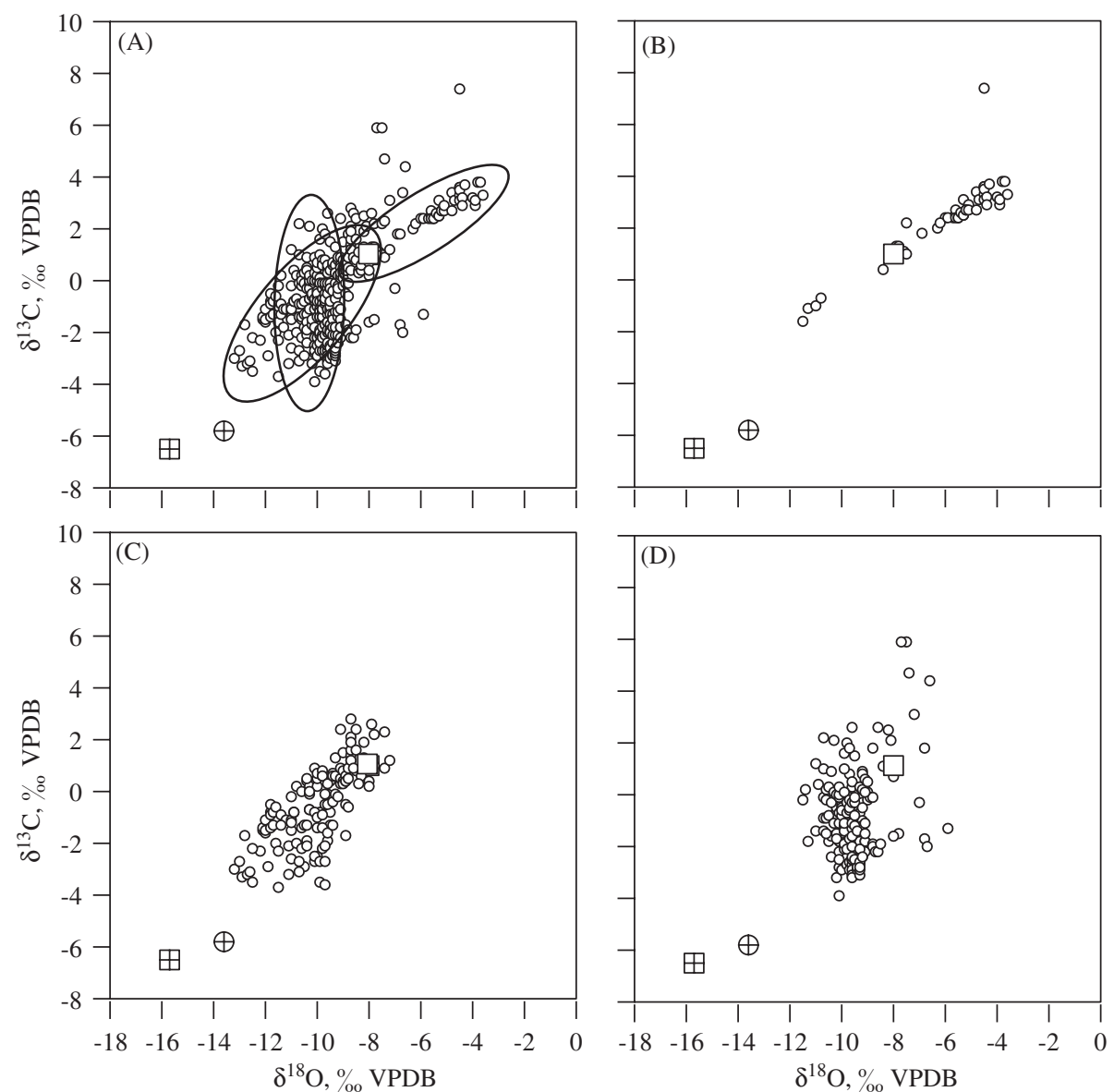

Fig. 4. Cross plots of $\delta^{18} \mathrm{O}$ and $\delta^{13} \mathrm{C}$ of bulk sediment carbonate from core 00-1E. Open square is average value of hand-picked carbonate grains from Swan Creek and North Eden Creek, used here to approximate the value of carbonate detritus; crossed circle is average value of $<63 \mu \mathrm{m}$ fraction of bulk sediment from seven streams surrounding Bear Lake; crossed square is average value of hand-picked tufa grains from three streams surrounding Bear Lake (see Table 4). (A) All data. Ovals delimit fields of data shown separately in panels B-D. (B) Holocene and marine oxygen-isotope stage (OIS) 5e. (C) OIS $5 \mathrm{a}-\mathrm{d}$ and OIS 7. (D) OIS $2-4$ and OIS 6.

chemistry of the overlying lake water. Furthermore, ostracode calcite $\delta^{18} \mathrm{O}$ often is isotopically enriched compared with inorganic calcite due to a vital effect (von Grafenstein et al., 1999; Leng and Marshall, 2004). Interpreting fluctuations in ostracode calcite $\delta^{13} \mathrm{C}$ is complex as it reflects the $\delta^{13} \mathrm{C}$ of the DIC of the surrounding water, which is affected by many factors, such as photosynthetic activity, temperature, dissolved $\mathrm{CO}_{2}$, methanogenesis and methane oxidation, sulfate reduction, and the $\delta^{13} \mathrm{C}$ of local inflow as influenced by the surrounding plant communities (Talbot and Kelts, 1990; Nordt et al., 1994; Kendall et al., 1995; Li and Ku, 1997; Lojen et al., 1999; Vreča, 2003 ).

Below $98 \mathrm{~m}$ core depth, $\delta^{18} \mathrm{O}_{\text {Candona }}$ exhibits large fluctuations on the order of $7.5 \%$, whereas $\delta^{13} \mathrm{C}_{\text {Candona }}$ varies less. Between 98 and $68 \mathrm{~m}$ depth, $\delta^{18} \mathrm{O}_{\text {Candona }}$ is overall more depleted, but again exhibits fluctuations $>7 \%$, as does $\delta^{13} \mathrm{C}_{\text {Candona. Between }} 65$ and $38 \mathrm{~m}$, stable isotope ratios in Candona sp. calcite are relatively high and exhibit numerous large $(\sim 5 \%$ ) fluctuations (Fig. 4). Between 38 and $10 \mathrm{~m}$ depth $\delta^{18} \mathrm{O}_{\text {Candona }}$ values stabilize and gradually decrease whereas $\delta^{13} \mathrm{C}_{\text {Candona }}$ variability remains high. Above $10 \mathrm{~m}, \delta^{18} \mathrm{O}_{\text {Candona }}$ increases $(\sim 8 \%$ ) and displays little variation, whereas $\delta^{13} \mathrm{C}_{\text {Candona }}$ remains depleted.

Ostracode $\delta^{18} \mathrm{O}$ values may be used to estimate $\delta^{18} \mathrm{O}_{\text {lake }}$ if a constant water temperature can be assumed and if the vital effect is known. In this study, when presenting ostracode-derived $\delta^{18} \mathrm{O}_{\text {lake }}$ values, we assume a bottomwater temperature of $4{ }^{\circ} \mathrm{C}$ and a vital effect correction of $-2.0 \%$ for Candona sp. $\delta^{18} \mathrm{O}$ values (von Grafenstein et al., 1999).

\subsection{Isotopes in core 00-1E bulk sediment}

We subdivided the stable isotope record from core $00-1 \mathrm{E}$ into six sections based on shifts in its isotopic characteristics (Figs. 3 and 4). Two aragonite-rich sections (68-61 and $9-0 \mathrm{~m}$ depth) exhibit enriched isotope values and a high $\delta^{18} \mathrm{O}_{\text {bulk }}-\delta^{13} \mathrm{C}_{\text {bulk }}$ correlation coefficient; two sections (100-70 and $37.5-10 \mathrm{~m}$ depth) are relatively depleted in ${ }^{18} \mathrm{O}$, especially the ostracode values, and the bulk sediment exhibit a low $\delta^{18} \mathrm{O}_{\text {bulk }}-\delta^{13} \mathrm{C}_{\text {bulk }}$ correlation coefficient; and finally, two sections (121-100 and 
61-37.5 m depth) have highly variable isotope values with a relatively high $\delta^{18} \mathrm{O}_{\text {bulk }}-\delta^{13} \mathrm{C}_{\text {bulk }}$ correlation coefficient (Table 5). Correlation coefficients are used in this paper simply as an additional description of the bulk sediment isotopic behavior that may be useful in differentiating between sections of core. Some authors use $\delta^{18} \mathrm{O}-\delta^{13} \mathrm{C}$ correlation coefficients in lacustrine sediments as an indicator of open or closed basins, with high correlation coefficients (high $r$-values) over 0.7 indicative of closed basin conditions (e.g. Talbot, 1990). Li and $\mathrm{Ku}$ (1997) demonstrated that endogenic carbonate produced in closed basin lakes can exhibit low $\delta^{18} \mathrm{O}-\delta^{13} \mathrm{C}$ correlation coefficients due to non-linear responses in the isotopic evolution of both $\delta^{18} \mathrm{O}$ and $\delta^{13} \mathrm{C}$ (e.g. if $\delta^{18} \mathrm{O}$ reached a steady state isotopic balance but $\delta^{13} \mathrm{C}$ continued to vary through biologic productivity then the $\delta^{18} \mathrm{O}-\delta^{13} \mathrm{C}$ correlation coefficient in endogenic carbonate would be low). We also acknowledge that some of the differences in $\delta^{18} \mathrm{O}_{\text {bulk }}$ might reflect differences in isotopic fractionation between calcite and aragonite (e.g. Böhm et al., 2000). The extent of this fractionation is minor compared to the shift in $\delta^{18} \mathrm{O}_{\text {bulk }}$ between sections, however.

\section{Paleoclimate interpretations}

\subsection{Inferred response of Bear Lake sediment to climatic change}

During glacial periods, lower temperatures and higher effective moisture (Benson, 1986; Lemons et al., 1996), and a shift in local vegetation to $\mathrm{C}_{3}$-dominated plant communities (Rozanski et al., 1993; Nordt et al., 1994), should decrease both $\delta^{18} \mathrm{O}_{\text {input }}$ and $\delta^{13} \mathrm{C}_{\text {input }}$ to Bear Lake. However, if the lake expanded over the flat northern half of Bear Lake valley, the surface-area-to-volume ratio, and associated evaporative loss would increase, at least during the initial stages of the transgression. We therefore assume that, even under a glacial climate, Bear Lake might generate relatively enriched endogenic carbonate.

Periods when the Bear River discharged directly into Bear Lake should be recognizable by the lowest $\delta^{18} \mathrm{O}$ values in endogenic carbonate compared with that of any other lake configuration, especially during periods when air temperature is low and winter precipitation dominates. The isotopic response of the lake to the input of Bear River is complicated by variables that affect the delivery of stream sediment to the core. If the detrital carbonate flux to the core site increases, then $\delta^{18} \mathrm{O}_{\text {bulk }}$ and $\delta^{13} \mathrm{C}_{\text {bulk }}$ approaches $\delta^{18} \mathrm{O}_{\text {detrital }}$ and $\delta^{13} \mathrm{C}_{\text {detrital. }}$. On the other hand, the mouth of the Bear River was never closer than $13 \mathrm{~km}$ from the core site where the impact of the distal river inflow might be difficult to decipher based on the bulk sediment. Unlike the bulk sediment, the isotopic value of ostracode calcite is not compromised by the detrital input; it decreases when the Bear River enters the lake.

Under warm/dry climates, we assume that Bear Lake is restricted to a topographically closed basin or has minimal outflow, similar to modern pre-diversion conditions. Its bulk carbonate is primarily endogenic aragonite with enriched isotope values in the bulk-sediment and ostracode carbonate.

\subsection{Synthesis and correlation with marine oxygen-isotope stages}

The available chronological control for core $00-1 \mathrm{E}$, while not definitive, is sufficient to roughly assign these core segments to marine oxygen-isotope stages (OIS) (Fig. 3). The chronology is based on ${ }^{14} \mathrm{C}$, U-series, and other data that are discussed in detail in a companion paper (Colman et al., in press).

\subsubsection{OIS 7}

The basal section of core 00-1E (121-100 m) contains sediment and ostracode calcite with variable and occasionally elevated stable isotope values, especially in the ostracodes (Fig. 3). The $\delta^{18} \mathrm{O}_{\text {bulk }}-\delta^{13} \mathrm{C}_{\text {bulk }}$ correlation coefficient in this section is high $(r=0.74, n=64$; Table 5). The stratigraphic position of this interval below an aragonite-rich interval that can be confidently assigned to OIS 5e, enriched ${ }^{18} \mathrm{O}$ and ${ }^{13} \mathrm{C}$ isotopes, and presence of aragonite at $\sim 103 \mathrm{~m}$ suggest that these sediments were deposited during OIS 7. The $\delta^{18} \mathrm{O}_{\text {Candona }}$ values suggest that $\delta^{18} \mathrm{O}_{\text {lake }}$ fluctuated between $\sim-6.5 \%$ (110 and $\left.102 \mathrm{~m}\right)$ and $\sim-14 \%$ ( 119 and $108-105 \mathrm{~m}$ ). Bear River was probably in contact with Bear Lake during the deposition of most negative $\delta^{18} \mathrm{O}_{\text {Candona }}$ and $\delta^{18} \mathrm{O}_{\text {bulk }}$ values. Given our understanding of aragonite formation in Bear Lake (Dean et al., 2006) the lake was not fully disconnected from the Bear River during the enriched $\delta^{18} \mathrm{O}_{\text {Candona }}$ and $\delta^{18} \mathrm{O}_{\text {bulk }}$

Table 5

Averaged values and statistical relation between $\delta^{18} \mathrm{O}$ and $\delta^{13} \mathrm{C}$ values in bulk sediment from Bear Lake core $00-1 \mathrm{E}$

\begin{tabular}{|c|c|c|c|c|c|c|}
\hline Depth (m) & Inferred OIS ${ }^{\mathrm{a}}$ & $n$ & $\delta^{18} \mathrm{O}(\%)$ & $\delta^{13} \mathrm{C}(\%)$ & $r$ & $p$-value \\
\hline $0-10.0$ & 1 & 28 & $-6.2 \pm 2.1$ & $2.0 \pm 1.3$ & 0.979 & $6.38 \times 10^{-24}$ \\
\hline $10.3-37.1$ & $2-4$ & 85 & $-9.5 \pm 0.9$ & $-0.8 \pm 1.6$ & 0.007 & $7.24 \times 10^{-1}$ \\
\hline $61.4-67.6$ & $5 \mathrm{e}$ & 21 & $-5.6 \pm 1.9$ & $2.9 \pm 1.7$ & 0.830 & $2.25 \times 10^{-9}$ \\
\hline $67.9-100.4$ & 6 & 103 & $-9.5 \pm 0.9$ & $-0.8 \pm 1.6$ & 0.416 & $8.60 \times 10^{-5}$ \\
\hline $100.8-120.6$ & 7 & 64 & $-10.4 \pm 1.4$ & $-0.5 \pm 1.4$ & 0.735 & $5.33 \times 10^{-11}$ \\
\hline
\end{tabular}

${ }^{\mathrm{a}} \mathrm{OIS}=$ marine oxygen-isotope stage. 
interval at $\sim 112 \mathrm{~m}$. The lack of aragonite in those sediments suggests that the lake's $\mathrm{Mg} / \mathrm{Ca}$ ratio did not cross the threshold necessary to produce aragonite. Bear Lake was topographically closed, highly evaporative, and fully disconnected from the Bear River during the aragonite interval at $103 \mathrm{~m}$, however. The $\delta^{18} \mathrm{O}_{\text {Candona }}$ values from the aragonite interval at $\sim 103 \mathrm{~m}$ are comparable to Candona values from the two other major aragonite intervals that have been confidently assigned to OIS $5 \mathrm{e}$ and 1 (Fig. 3).

\subsubsection{OIS 6}

The overlying section $(\sim 100-69 \mathrm{~m})$ contains sediment with depleted and relatively consistent $\delta^{18} \mathrm{O}_{\text {bulk }}$ values, variable $\delta^{13} \mathrm{C}_{\text {bulk }}$ values, and variable Candona stable isotope values (Fig. 3). The $\delta^{18} \mathrm{O}_{\text {bulk }}-\delta^{13} \mathrm{C}_{\text {bulk }}$ correlation coefficient in these sediments $(r=0.42, n=103$; Table 5) is lower than in the underlying section, indicating a change in the sediment isotopic characteristics. The $\delta^{13} \mathrm{C}_{\text {bulk }}$ varies by nearly $5 \%$, considerably more than $\delta^{18} \mathrm{O}_{\text {bulk, }}$ which hovers around $-9.7 \pm 0.6 \%$ o $(n=94)$. This value is generally $1-2 \%$ o lower than our inferred $\delta^{18} \mathrm{O}_{\text {detrital }}$ value, suggesting that, while endogenic carbonate is present, detrital carbonate probably constitutes a large portion of the total carbonate. Based on its stratigraphic position between two aragonitic intervals, and its isotopic characteristics, we assign this section to OIS 6.

The $\delta^{18} \mathrm{O}_{\text {Candona }}$ values range from -5.7 to $-13.2 \%$, and exhibit more variability than $\delta^{18} \mathrm{O}_{\text {bulk }}$. There are relatively few ostracode results on which to base confident conclusions, but the $\delta^{18} \mathrm{O}_{\text {Candona }}$ values that are available suggest that $\delta^{18} \mathrm{O}_{\text {lake }}$ during OIS 6 fluctuated between -10 and $-17 \%$. Equally variable are the $\delta^{13} \mathrm{C}_{\text {Candona }}$ values, which fluctuate between approximately 0 and $-7.5 \%$. Assuming that $\delta^{18} \mathrm{O}_{\text {input }}$ was more negative than the present (present $\approx-17 \%$ ) during OIS 6 , then the majority of the

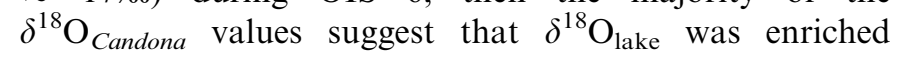
(possibly by as much as $10 \%$ ), suggesting that most of OIS 6 was cold and dry (Fig. 4). The Candona stable isotope data show significant depletions in $\delta^{18} \mathrm{O}_{\text {lake }}$ and $\delta^{13} \mathrm{C}_{\text {lake }}$ between $97-85$ and $82-72 \mathrm{~m}$ depth (Fig. 3). While the chronology does not allow for detailed comparisons to other climate records, the two depletion events in the Bear Lake OIS 6 record may be correlative with the two OIS 6 interstadials in the Devils Hole and SPECMAP records. Alternatively, they may be related to pulses of glacial meltwater discharged from the Uinta Mountains.

\subsubsection{OIS $5 e$}

Both bulk sediment and Candona isotope values increase at $68 \mathrm{~m}$, and aragonite dominates the bulk-sediment mineralogy, similar to the upper Holocene sediments (Fig. 3), and the $\delta^{18} \mathrm{O}_{\text {bulk }}-\delta^{13} \mathrm{C}_{\text {bulk }}$ correlation coefficient is high $(r=0.83, n=21$; Table 5). The aragonite at $65 \mathrm{~m}$ has a U-Th age of $\sim 128 \mathrm{ka}$ (Colman et al., in press) and the Blake paleomagnetic excursion $(\sim 121 \mathrm{ka})$ has been tentatively identified at $64.3 \mathrm{~m}$. We assign this central section $(\sim 68-62 \mathrm{~m})$ of the core to OIS 5e. The enriched bulk sediment and Candona stable isotope values indicate that Bear Lake was topographically closed, highly evaporative, and biologically productive during the peak of the last interglaciation. The most enriched $\delta^{18} \mathrm{O}_{\text {Candona }}$ values suggest $\delta^{18} \mathrm{O}_{\text {lake }}$ was as high as $-5.3 \%$. The ${ }^{13} \mathrm{C}$-depleted ostracode calcite is indicative of increased chemical reactions (e.g. organic decomposition, methane oxidation, etc.) in the lake sediments during the last interglaciation. The overall hydrologic and isotopic characteristics of Bear Lake were probably similar to modern (pre-1912). The depletion event at $64 \mathrm{~m}$ is best explained by an incursion of Bear River water into the lake.

\subsubsection{OIS $5 d$ to $5 a$}

We interpret the decrease in isotopic values of bulk sediment and the cessation of aragonite deposition at $\sim 61 \mathrm{~m}$ as the termination of OIS 5e (Fig. 3). Ostracode $\delta^{18} \mathrm{O}$ values fluctuate but overall remain high until $\sim 37.5 \mathrm{~m}$, however. Based on its stratigraphic position and isotopic characteristics we assign the sediment between $\sim 61$ and $37.5 \mathrm{~m}$ to the later substages of OIS 5. Overall, the $\delta^{18} \mathrm{O}_{\text {bulk }}-\delta^{13} \mathrm{C}_{\text {bulk }}$ correlation coefficient in this section is high $\left(r=0.77, n=74\right.$; Table 5). The enriched $\delta^{18} \mathrm{O}_{\text {Candona }}$ and the brief occurrence of aragonite at $\sim 56 \mathrm{~m}$ (Fig. 3) suggests that Bear Lake was at times confined to a topographically closed basin, although two large depletion events at 54 and $44 \mathrm{~m}$ and two weaker events at $\sim 59$ and $50 \mathrm{~m}$ (more pronounced in the carbon than in the oxygen) suggest periodic input from the Bear River.

The $\delta^{18} \mathrm{O}_{\text {Candona }}$ values from this section are more variable than $\delta^{18} \mathrm{O}_{\text {bulk }}$, but the two track one another $(r=0.72, n=20)$, as they do for carbon $(r=0.84, n=20)$. The $\delta^{18} \mathrm{O}_{\text {Candona }}$ values suggest that $\delta^{18} \mathrm{O}_{\text {lake }}$ was periodically enriched $(\sim-6$ to $-8 \%$ ) during the latter part of OIS 5 , and that the lake received four ${ }^{18} \mathrm{O}$-depleted influxes of water at $61,54,49.5$, and $44 \mathrm{~m}$, with the lake becoming progressively more depleted during each (Fig. 3). The magnitude of these depletions implies the impact of the Bear River. The $\delta^{13} \mathrm{C}_{\text {Candona }}$ values in this section of core are more enriched than in the previous section, suggesting that the mechanism that produced more depleted $\delta^{13} \mathrm{C}_{\text {Candona }}$ during OIS 5e was no longer effective. The $\delta^{13} \mathrm{C}_{\text {Candona }}$ values, however, are consistently lower than $\delta^{13} \mathrm{C}_{\text {bulk }}$, indicating that ${ }^{12} \mathrm{C}$-liberating processes were still operating within the lake sediment. The isotopic and hydrologic budgets of Bear Lake during the deposition of this segment of core were apparently complex, and resulted in bulk-sediment and ostracode isotope fluctuations that only weakly parallel the well-known OIS $5 \mathrm{a}-5 \mathrm{~d}$ structure of other paleoclimate records (e.g. SPECMAP and Devils Hole).

\subsubsection{OIS 4 to 2}

Between 37.5 and $10 \mathrm{~m}$ ostracode $\delta^{18} \mathrm{O}$ values are lower and more stable than below, whereas the bulk sediment values remain similar (Fig. 3). The correlation between 
$\delta^{18} \mathrm{O}_{\text {bulk }}$ and $\delta^{13} \mathrm{C}_{\text {bulk }}$ is low, however $(r=0.01, n=85$; Table 5). Based on the isotopic data and the stratigraphic position below the uppermost aragonitic interval, we assign the sediment between 37.5 and $10 \mathrm{~m}$ to OIS 4 through 2 . Between $37-27 \mathrm{~m}, \delta^{18} \mathrm{O}_{\text {bulk }}$ and $\delta^{18} \mathrm{O}_{\text {Candona }}$ display similar trends suggesting that both are responding to variations in $\delta^{18} \mathrm{O}_{\text {lake. }}$. The $\delta^{18} \mathrm{O}_{\text {Candona }}$ values suggest that $\delta^{18} \mathrm{O}_{\text {lake }}$ varied from $\sim-10$ to $-13 \%$. This is similar to the $\delta^{18} \mathrm{O}_{\text {lake }}$ value that we infer for OIS 6 , and again implies that the early Wisconsin climate at Bear Lake was cold and dry (see Section 5.2.2). Above $27 \mathrm{~m}$ the $\delta^{18} \mathrm{O}_{\text {Candona }}$ values begin to fluctuate out of phase with $\delta^{18} \mathrm{O}_{\text {bulk }}$, and both $\delta^{13} \mathrm{C}_{\text {Candona }}$ and $\delta^{13} \mathrm{C}_{\text {bulk }}$ begin to decrease. The decrease in $\delta^{13} \mathrm{C}$ may have been related to several factors, such as a decrease in lake productivity, or a decrease in $\delta^{13} \mathrm{C}_{\text {inflow }}$ due to vegetation change (e.g. Nordt et al., 1994; Biedenbender et al., 2004). The depletions in $\delta^{18} \mathrm{O}_{\text {Candona }}$ between $\sim 25$ and $19 \mathrm{~m}$ occur in concert with increases in $\delta^{18} \mathrm{O}_{\text {bulk }}$ to near $\delta^{18} \mathrm{O}_{\text {detrital }}$ values, suggesting that several influxes of water depleted in ${ }^{18} \mathrm{O}$ occurred in association with influxes of detrital carbonate (Fig. 3). The $\delta^{18} \mathrm{O}_{\text {Candona }}$ values at 25 and $19 \mathrm{~m}$ imply that $\delta^{18} \mathrm{O}_{\text {lake }}$ decreased to $\sim-16.5 \%$ during both events. The negative $\delta^{18} \mathrm{O}_{\text {lake }}$ values suggest that the Bear River probably discharged directly into Bear Lake during these depletion events. Between $\sim 17$ and $10 \mathrm{~m}$, all of the stable isotope values stabilize and persist at negative and invariable values. The $\delta^{18} \mathrm{O}_{\text {Candona }}$ values suggest that $\delta^{18} \mathrm{O}_{\text {lake }}$ was $\sim-14 \%$ at the time these sediments were deposited. The lake was probably overflowing with direct input from the Bear River.

\subsubsection{The Holocene (OIS 1)}

An increase in $\delta^{18} \mathrm{O}_{\text {bulk }}, \delta^{13} \mathrm{C}_{\text {bulk }}$, and $\delta^{18} \mathrm{O}_{\text {Candona }}$ occurs at $\sim 10 \mathrm{~m}$, and aragonite again dominates the bulk sediment mineralogy (Fig. 3). On the basis of correlation of these properties with those of ${ }^{14} \mathrm{C}$-dated gravity cores taken in 1996 (Rosenbaum et al., 2001), the sediment above $10 \mathrm{~m}$ was deposited during the Holocene. Stable isotope values in this segment are enriched, and the $\delta^{18} \mathrm{O}_{\text {bulk }}-\delta^{13} \mathrm{C}_{\text {bulk }}$ correlation coefficient is high $(r=0.98, n=28$; Table 5) and along with the aragonitic bulk sediments, suggests that Bear Lake was topographically closed, evaporative, and productive throughout the Holocene. The abrupt isotopic enrichment at $\sim 10 \mathrm{~m}$ records the transition out of the Pleistocene. Evidence for the major climate changes known from elsewhere during the Pleistocene-Holocene transition do not appear to be present in our coarsely sampled record, although $\delta^{18} \mathrm{O}_{\text {bulk }}$ exhibits a negative excursion before attaining Holocene values. The prominent depletion event at $\sim 7.2 \mathrm{~m}$ records an interval of increased inflow during the early Holocene. Because of the coarser sampling interval, the event at $\sim 7.2 \mathrm{~m}$ was not represented in the ostracode data. The decrease in $\delta^{18} \mathrm{O}_{\text {bulk }}$ suggests that Bear Lake overflowed at this time, and was likely accompanied by a shoreline transgression (Laabs and Kaufman, 2003), which would have increased the possibility for chemical and isotopic mixing with Bear River.
Like the bulk sediment, the $\delta^{18} \mathrm{O}_{\text {Candona }}$ values suggest rapid enrichment of $\delta^{18} \mathrm{O}_{\text {lake }}$ at the Pleistocene-Holocene transition. The $\delta^{13} \mathrm{C}_{\text {Candona }}$ values in the upper $10 \mathrm{~m}$ of the core are more depleted than $\delta^{13} \mathrm{C}_{\text {bulk }}$ values, and is probably due to increased productivity during the Holocene (enhanced decomposition of ${ }^{12} \mathrm{C}$-enriched organic matter on the lake floor), and possibly the rejuvenation of other chemical reactions, such as methane oxidation.

\section{Conclusions}

1. The $\delta^{18} \mathrm{O}_{\text {input }}$ and $\delta^{13} \mathrm{C}_{\text {input }}$ values from springs and streams surrounding Bear Lake are similar to one another, averaging roughly -17 and $\sim-9.5 \%$, respectively. Evaporation within Bear Lake increases $\delta^{18} \mathrm{O}_{\text {input }}$ by nearly $10 \%$, resulting in a $\delta^{18} \mathrm{O}_{\text {lake }}$ value of $\sim-8 \%$. Degassing and biologic activity in the lake increase $\delta^{13} \mathrm{C}_{\text {input }}$ to $\sim-2 \%$.

2. The isotopic value of Bear Lake has fluctuated dramatically over the last $250,000 \mathrm{yr}$. Based on the available chronology, the large-scale trends in $\delta^{18} \mathrm{O}_{\text {lake }}$ broadly parallel glacial-interglacial fluctuations known from other proxy climate records. Superimposed on the climate signal are the confounding effects of sporadic input of the Bear River (e.g. during OIS 5 and 2-4), and of the changes in the proportion of detrital to endogenic carbonate.

3. Ostracode calcite records large fluctuations in the isotopic value of Bear Lake water $\left(\delta^{18} \mathrm{O}_{\text {lake }}\right.$ ranges from $\sim-17$ to $-5 \%$ ) and can be interpreted without the uncertainty that results from fluctuating carbonate detritus. The ostracode results indicate that bulksediment carbonate responded less sensitively to changes in $\delta^{18} \mathrm{O}_{\text {lake }}$ over large sections of the core.

4. $\delta^{13} \mathrm{C}_{\text {Candona }}$ is several per mil lower than $\delta^{13} \mathrm{C}_{\text {bulk }}$ during the deposition of the main aragonitic sections (OIS 7a and $5 \mathrm{e}$ ) and throughout the Holocene. Chemical reactions such as methane oxidation or sulfate reduction may be enhanced when the lake is topographically closed.

5. The oxygen- and carbon-isotopic record from core 00$1 \mathrm{E}$ is interpreted as follows.

OIS 7: During the penultimate interglaciation, Bear Lake apparently fluctuated between a topographically closed and open basin. It is unclear if the fluctuations were in response to changes in effective moisture, possibly associated with substages within OIS 7, or to non-climatically induced fluctuations in the input from the Bear River.

OIS 6: The penultimate glacial climate at Bear Lake was apparently cold and dry and associated with an unexpectedly enriched $\delta^{18} \mathrm{O}_{\text {lake }}$. Two large depletion events during OIS 6 may be correlative with OIS 6 interstadials preserved in other global and regional climate records.

OIS 5: During the peak of the last interglaciation (OIS 5e), the hydrologic and isotopic 
characteristics of Bear Lake were probably similar to the pre-diversion modern lake. During much of the later substages of OIS 5 the lake periodically received water from the Bear River and probably overflowed to some degree.

OIS 4 to 2: During the last glacial cycle, the influence of climate on the isotopic proxies was masked by interactions with the Bear River and are difficult to decipher. The depleted ostracode $\delta^{18} \mathrm{O}$ suggests that Bear Lake was aggressively overflowing and fed by the Bear River throughout OIS 2.

OIS 1: During the Holocene, sustained isotopic enrichment and the dominance of aragonite in the bulk sediment indicates that the lake remained topographically closed, except for a brief overflow episode and potential mixing with the Bear River, at a depth of $\sim 7.5 \mathrm{~m}$.

6. The stable isotope data suggest that the Bear River repeatedly and intermittently discharged into Bear Lake during the last 250,000 yr. The Holocene configuration of an isolated, aragonite-producing lake confined to the southern end of Bear Lake valley is unusual in context of the last $250,000 \mathrm{yr}$.

\section{Acknowledgements}

The GLAD800 coring at Bear Lake was sponsored jointly by the USGS, NSF, ICDP, and conducted by DOSECC. Funding for this work was provided by the US Geological Survey-Earth Surface Dynamics Program, and the Geological Society of America. We thank David Dettman and Chris Eastoe (University of Arizona) and Rebecca Clotts (University of Minnesota) for the isotopic analyses, and Doug Schurrenberger, Steve Colman, R. Scott Anderson, and Bruce Hungate for their input. Scott Tolentino and Bryce Nelson of the Utah Division of Natural Resources helped immensely to locate and sample the lake-marginal and sub-lacustrine springs. Gary Skipp (US Geological Survey, Denver) performed the X-ray diffraction analyses. We appreciate the reviews by Ulrich von Grafenstein and an anonymous reviewer which contributed to the improvement of this paper.

\section{Appendix A. Supplementary data}

The online version of this article contains additional supplementary data. Please visit doi:10.1016/j.quascirev. 2005.12.011.

\section{References}

Amayreh, J., 1995. Lake evaporation: A model study. Ph.D. Dissertation, Utah State University, Logan, UT, 178pp.
Benson, L., 1986. The sensitivity of evaporation rate to climate changeresults of an energy-balance approach. Water Resources Investigations Report 86-4148. US Geological Survey, Denver, CO, 40 pp.

Biedenbender, S.H., McClaran, M.P., Quade, J., Weltz, M.A., 2004. Landscape patterns of vegetation change indicated by soil carbon isotope composition. Geoderma 119, 69-83.

Birdsey, P.W., 1989. The limnology of Bear Lake, Utah-Idaho, 1912-1988: A literature review. Utah Department of Natural Resources, Publication 89-5, Salt Lake City, UT, 113pp.

Böhm, F., Joachimski, M.M., Dullo, W.-C., Eisenhauer, A., Lehnert, H., Reitner, J., Wörheide, G., 2000. Oxygen isotope fractionation in marine aragonite of coralline sponges. Geochimica et Cosmochimica Acta 64, 1695-1703.

Bright, J., 2003. A $\sim 240,000$ year record of oxygen-isotope and ostracodefaunal fluctuations, Bear Lake, Utah-Idaho. Masters Thesis, Northern Arizona University, Flagstaff, AZ, 131pp.

Bright, J., Kaufman, D., 2005. Ostacodes in core BL00-1-D from Bear Lake, Utah and Idaho: Preliminary analyses. US Geological Survey Open-File Report 2005-1226. http://pubs.usgs.gov/of/2005/1226/.

Colman, S., Kaufman, D., Heil, C., King, J., Dean W., Rosenbaum, J. R., Bischoff, J., Perkins, M., in press. Age models for a continuous 250kyr Quaternary lacustrine record from Bear Lake, Utah-Idaho. Quaternary Science Reviews.

Dean, W., Rosenbaum, J., Skipp, G., Colman, S., Forester, R., Liu, A., Simmons, K., Bischoff, J., 2006. Unusual Holocene and late Pleistocene carbonate sedimentation in Bear Lake, Utah and Idaho, USA. Sedimentary Geology 185, 93-112.

Dean, W., Rosenbaum, J., Haskell, B., Kelts, K., Schurrenberger, D., Valero-Garces, B., Cohen, A., Davis, O., Dinter, D., Nielson, D., 2002. Progress in global lake drilling holds potential for global change research. EOS, Transactions of the American Geophysical Union 83 (9), 85 90-91.

Dover, J.H., 1995. Geologic map of the Logan 30' x 60' quadrangle, Cache and Rich counties, Utah, and Lincoln and Uinta counties, Wyoming. US Geological Survey, Miscellaneous Investigation Series, Map I-2210.

Eugster, H.P., Jones, B.F., 1979. Behavior of major solutes during closedbasin brine evolution. American Journal of Science 279, 609-631.

Kendall, C., Sklash, M.G., Bullen, T.D., 1995. Isotope tracers of water and solute sources in catchments. In: Trudgill, S.T. (Ed.), Solute Modeling of Catchment Basins. Wiley, New York, pp. 262-303.

Laabs, B.J., Kaufman, D.S., 2003. Quaternary highstands in Bear Lake valley, Utah and Idaho. Geological Society of America Bulletin 115, 463-478.

Lemons, D.R., Milligan, M.R., Chan, M.A., 1996. Paleoclimatic implications of late Pleistocene sediment yield rates for the Bonneville Basin, northern Utah. Palaeogeography, Palaeoclimatology, Palaeoecology $123,147-159$

Leng, M.J., Marshall, J.D., 2004. Palaeoclimate interpretation of stable isotope data from lake sediment archives. Quaternary Science Reviews 23, 811-831.

Li, H.-C., Ku, T.-L., 1997. $\delta^{13} \mathrm{C}-\delta^{18} \mathrm{O}$ covariance as a paleohydrological indicator for closed-basin lakes. Palaeogeography, Palaeoclimatology, Palaeoecology 133, 69-80.

Lojen, S., Ogrinc, N., Dolenec, T., 1999. Decomposition of sedimentary organic matter and methane formation in the recent sediment of Lake Bled (Slovenia). Chemical Geology 159, 223-240.

McCalpin, J.P., 1993. Neotectonics of the northeastern Basin and Range margin, western USA. Zeitschruft fur Geomorphologie, Supplementband 94, 137-157.

McConnell, W.J., Clark, W.J., Sigler, W.F., 1957. Bear Lake - its fish and fishing. Utah State Department of Fish and Game, Idaho Department of Fish and Game, Wildlife Management Department of Utah State Agricultural College, 76pp.

Nordt, L.C., Boutton, T.W., Hallmark, C.T., Waters, M.R., 1994. Late Quaternary vegetation and climate changes in central Texas based on the isotopic composition of organic carbon. Quaternary Research 41, 109-120. 
Oriel, S.S., Platt, L.B., 1980. Geologic map of the Preston $1^{\circ} \times 2^{\circ}$ quadrangle, southeastern Idaho and western Wyoming. US Geological Survey, Miscellaneous Investigations Series, Map I-1127.

Rosenbaum, J.G., Dean, W.E., Bright, J., Colman, S.M., Bischoff, J.L., Anderson, R.S., Forester, R.M., Kaufman, D.S., 2001. Climate record in a 240-kyr sediment core from Bear Lake, Utah-Idaho. EOS, Transactions of the American Geophysical Union 82 (47), Fall Meeting, Supplement Abstract PP22A-0500.

Rozanski, K., Araguas-Arguas, L., Gonfiantini, R., 1993. Isotopic patterns in modern global precipitation. In: Stewart, P.K., Lohmann, K.C., McKenzie, J., Savin, S. (Eds.), Climate Change in Continental Isotopic Records, Geophysical Monograph, vol. 78. American Geophysical Union, Washington, DC pp. 1-36.

Spangler, L.E., 2001. Delineation of recharge areas for karst springs in Logan Canyon, Bear River Range, northern Utah. In: Kuniasky, E. L. (Ed.), US Geological Survey Karst Interest Group Proceedings. WaterResources Investigations Report 01-4011, Atlanta, GA, p. 186-193.

Talbot, M.R., 1990. A review of the palaeohydrological interpretations of carbon and oxygen isotope ratios in primary lacustrine carbonates. Chemical Geology 80, 261-279.
Talbot, M., Kelts, K., 1990. Paleolimnological signatures from carbon and oxygen isotopic ratios in carbonates from organic carbon-rich lacustrine sediments. In: Katz, B.J. (Ed.), Lacustrine Basin Exploration: Case Studies and Modern Analogs. American Association of Petroleum Geologists, Tulsa, OK, pp. 99-112.

von Grafenstein, U., 2002. Oxygen-isotope studies of ostracodes from deep lakes. In: Holmes, J.A., Chivas, A.R. (Eds.), The Ostracoda: Applications in Quaternary Research. Geophysical Monograph, vol. 131. American Geophysical Union, Washington DC, pp. 249-266.

von Grafenstein, U., Erlernkeuser, H., Trimborn, P., 1999. Oxygen and carbon isotopes in modern fresh-water ostracode valves: assessing the vital offsets and autecological effects of interest for palaeoclimate studies. Palaeogeography, Palaeoclimatology, Palaeoecology 148, $133-152$.

Vreča, P., 2003. Carbon cycling at the sediment-water interface in a eutrophic mountain lake (Jezero na Planini pri Jezeru, Solvenia). Organic Geochemistry 34, 671-680.

Williams, J.S., Allen, D.W., Parker, V., 1962. Recent history of Bear Lake Valley, Utah-Idaho. American Journal of Science 260, 24-36. 